\title{
REGENERATION OF TRANSGENIC OIL PALM CARRYING GFP GENE USED AS A VISUAL SELECTABLE MARKER
}

\author{
NA'IMATULAPIDAH ABDUL MAJID* and GHULAM KADIR AHMAD PARVEEZ*
}

\begin{abstract}
Green fluorescent protein (GFP) has been widely used as a visual selectable marker for plant transformation. Transformed cells could be easily screened directly under ultraviolet/blue light without the need for any solution or substrate. In this study, oil palm embryogenic calli were bombarded with a transformation vector, p35SCaMV-sgfpS65T, carrying a modified version of gfp gene driven by the $35 S$ promoter. Upon bombardment, the expression of gfp in embryogenic calli was monitored visually while the regeneration of the embryogenic calli was on-going. Regenerated plantlets on medium without selection agent demonstrated that only some parts of the plants showed GFP expression. When gfp gene was co-bombarded with plasmid pAHC25 carrying Basta resistant gene (bar), and the transformed embryogenic calli were regenerated on medium containing herbicide Basta, regenerated plantlets obtained also showed GFP expression in some parts of the plantlets instead of in the whole plant. Molecular analysis revealed the presence of gfp transgene in the transgenic plants. The possible reasons for the failure to obtain the whole plant expressing gfp gene will be discussed.
\end{abstract}

Keywords: transformation, oil palm, green fluorescence protein (GFP) and visual selectable marker.

Date received: 1 July 2016; Sent for revision: 28 July 2016; Received in final form: 12 September 2016; Accepted: 6 October 2016.

\section{INTRODUCTION}

Transgenic plants have been planted commercially since 1996 and the planted area is increasing annually. The latest update from the International Service for Acquisition of Agribiotech Applications (ISAAA) shows that total areas planted worldwide with transgenic crops has reached 179.7 million hectares in 2015 (James, 2015). This involves planting of crops such as soyabean, maize, cotton, squash and papaya in 28 countries. Oil palm, being the major oil producing crop in the world, could benefit from this technology through increasing yield as well as producing novel high value added products.

\footnotetext{
* Malaysian Palm Oil Board,

6 Persiaran Institusi,

Bandar Baru Bangi, 43000 Kajang, Selangor, Malaysia.

E-mail: parveez@mpob.gov.my
}

Genetic engineering could help in introducing new traits into oil palm faster than could be obtained through classical breeding due to its long gestation period. Among the traits targeted from transgenic oil palms are high oleic acid, high palmitoleic acid and synthesising biodegradable plastics (Parveez et al., 2015a, b). In order to genetically modify oil palm, a reliable gene transfer method is essential. Transgenic oil palm was first reported more than 15 years ago using microprojectile bombardment and later by Agrobacterium-mediated protocol. However, the transformation efficiency was considerably low, at $\sim 0.7 \%-1.5 \%$ (Parveez, 2000; Masli et al., 2009).

It is of interest to increase the transformation efficiency of oil palm for effective modification of this crop. Among the considered approaches for improving the oil palm transformation efficiency are via the application of various transformation methods and different selection agents for the 
selection of transformants (Izawati et al., 2015). Besides microprojectile bombardment and Agrobacterium-mediated, transformation of oil palm protoplasts using polyethylene glycol and DNA microinjection was also initiated (Masani et al., 2013; 2014). However, production of transgenic oil palm plantlets is yet to be achieved. On the effect of selection agent on oil palm transformation, minimal inhibitory concentration studies showed that herbicides Basta and hygromycin are the most effective selectable agents as they could kill the untransformed cells at a very low concentration (Parveez et al., 1996; 2007). Basta and hygromycin were also shown to be the effective selection agents for other monocots such as rice (Zhao et al., 2011; Htwe et al., 2014), turfgrass (Song et al., 2013) and finger millet (Ignacimuthu and Ceasar, 2012). Initial regeneration of transgenic oil palm was obtained after transformed oil palm calli were selected on herbicide Basta. Selection using mannose (Joersbo et al., 1998), as selection agent, was later reported (Bahariah et al., 2012; 2013). Selection using mannose posed difficulty in the identification of individual events and calculation of the transformation efficiency due to the selection nature, which involved starving the untransformed cells instead of killing them. This has also resulted in the regeneration of many escapes or chimeric plants. Recently, production of transgenic oil palm using 2-deoxyglucose (2-DOG) (Kunze et al., 2001), as the selection agent was reported, however, the transformation efficiency was only around 1.0\% (Masli et al., 2012; Izawati et al., 2015).

As selection using chemicals, such as Basta, mannose and 2-DOG, failed to increase the efficiency of oil palm transformation, evaluation of visual selection system was later considered. One of the popular visual selection systems is the green fluorescent protein (GFP), which is based on $g f p$ gene isolated from jellyfish (Chalfie et al., 1994; Heim et al., 1994). This selection system is considered as a universal reporter gene because it does not require any chemical/substrate/co-factor to produce the green fluorescence. Moreover, it is stable in plant cells, species independent and nondestructive (Heim et al., 1994). The expression of the gene could be detected and monitored in real time either in vivo or in situ making it very effective for studying gene function. The use of $g f p$ as selectable marker gene in plant transformation has been successfully reported for many plants such as sugar-cane (Elliot et al., 1999), oat (Kaeppler et al., 2000), rice (Vain et al., 2000), bromegrass (Nakamura and Ishikawa, 2006), petunia (Mubmann et al., 2011) and Anthurium (Zhao et al., 2010). It was reported to reduce the time and amount of tissue handling in rice transformation (Vain et al., 2000). Besides, gfp gene was also used to study the promoter activity in soyabean (Hernandez-Garcia et al., 2010), low gene expression in Arabidopsis (Xiao et al., 2010), the cytoprotective and subcellular targeting in cotton (Lay et al., 2014) and organelle localisation in rice (Wang et al., 2007). Furthermore, the $g f p$ gene is useful to study functionality of candidate genes related to drought stress as demonstrated in barley (Nagy et al., 2011). The gfp expressing Aspergillus flavus fungus was also used to study fungal infection in cottonseed (Rajasekaran et al., 2008).

As described above, it was clearly demonstrated that GFP could be used as an effective selection marker in many plant species and this could be conveniently applied to oil palm. Application of GFP selection marker could result in an increased transformation efficiency as it is easy to visualise the transformed oil palm cells. Efforts to use $g f p$ as selectable marker gene was initiated by studying the transient expression and factors affecting the expression of $g f p$ gene in oil palm tissues such as embryogenic calli and immature embryos (Majid and Parveez, 2007; Parveez and Majid, 2008). High intensity and long-term transient expression of $g f p$ gene was detected in bombarded oil palm tissues but the regeneration of transgenic oil palm expressing $g f p$ gene is yet to be reported. The objectives of this study are to regenerate transgenic oil palm expressing the $g f p$ gene in the whole plant and to use the gene as an alternative selectable marker gene for selection of transformants. The $\operatorname{sgfp}(\mathrm{S65T})$ gene version, which has been reported to show the most intense and longest expression in several recent transient expression (Majid and Parveez, 2007), was used in this study with the target of increasing the transformation efficiency.

\section{MATERIALS AND METHODS}

\section{Plant Materials}

Oil palm embryogenic calli were derived from calli regenerated from immature leaf cultured on EC medium containing MS salts (Murashige and Skoog, 1962), $0.1 \mathrm{~g}$ litre $^{-1}$ myo-Inositol and L-glutamin, Y3 vitamins (Eeuwans, 1976), $5 \times 10^{-5} \mathrm{M} \mathrm{2,4-D,0.25 \%}$ activated charcoal, 3\% sucrose, and $0.7 \%$ agar, incubated in the dark at $28^{\circ} \mathrm{C}$ (Parveez, 1998). All calli formed were subcultured once a month onto the similar medium until all the calli matured into embryogenic calli.

\section{Gene Constructs}

The gfp gene construct used in this study was p35SCaMV-sgfpS65T (Sheen et al., 1995). Basta selectable marker construct used for cobombardment or individually (for non- $g f p$ gene control) was pAHC25 (Christiensen et al., 1992). Detailed schematic representations of the constructs are given in Figure 1. 


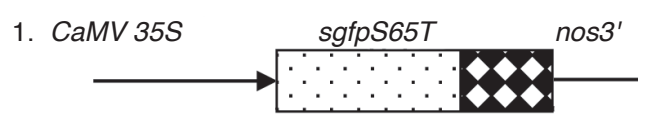

p35CaMV-sgfpS65T ( $4.09 \mathrm{~kb})$

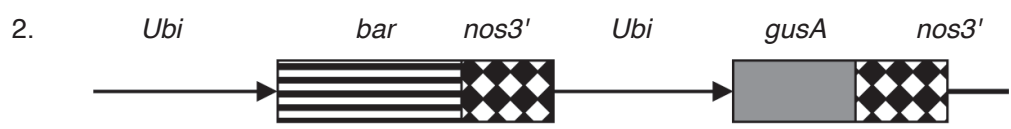

pAHC25 (4.5 kb)

Legend:

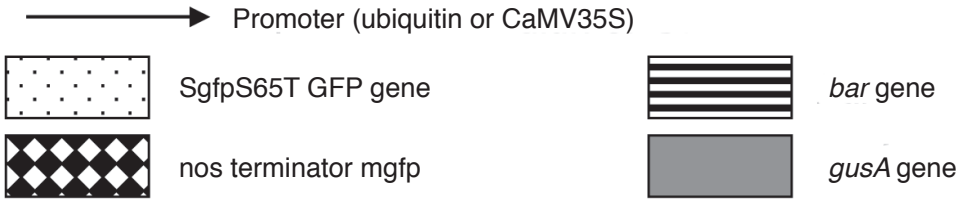

Figure 1. Plasmids used in evaluating green fluorescent protein (GFP) as a selectable marker for oil palm transformation.

\section{Large Scale Plasmid Isolation}

In this study, large scale plasmid isolation was carried out to isolate large quantity of plasmid DNA for many applications especially bombardments. Small scale isolation could also be carried out, however, large scale isolation is the most practical. A single colony from freshly grown E. coli containing either the p35SCaMV-sgfpS65T or pAHC25 constructs was picked and cultured in $10 \mathrm{ml}$ of LB medium $(0.1 \mathrm{~g} \mathrm{NaCl}, 0.1 \mathrm{~g}$ tryptone and $0.05 \mathrm{~g}$ yeast extract) supplemented with $50 \mu \mathrm{g} \mathrm{ml}^{-1}$ of ampicillin. One $\mathrm{ml}$ of overnight culture was then inoculated into $500 \mathrm{ml}$ of LB medium containing the same concentration of ampicillin. The overnight culture was transferred into large centrifuge bottles and the cells were pelleted by centrifugation (4000 rpm, 10 min and $4^{\circ} \mathrm{C}$ ). DNA isolation was carried out by using the QIAGEN Maxiprep kit. The supernatant was removed and the cell pellets were resuspended in $10 \mathrm{ml}$ of Buffer P1. The mixture was vortexed until no cell clumps remained. Buffer P2 $(10 \mathrm{ml})$ was added and mixed gently by inverting four to six times and the mixture was incubated for $5 \mathrm{~min}$ at room temperature. Then, chilled Buffer P3 $(10 \mathrm{ml})$ was added slowly, mixed and left on ice for $20 \mathrm{~min}$. The mixture was centrifuged at $13000 \mathrm{rpm}$ for 40 min at $4^{\circ} \mathrm{C}$. While centrifuging, a QIAGEN-tip 500 was equilibrated by allowing $10 \mathrm{ml}$ of QBT buffer to flow through the resin by gravity. The supernatant from the GSA bottle was loaded into the column promptly. The QIAGEN-tip was washed twice with $30 \mathrm{ml}$ of Buffer QC. A $30 \mathrm{ml}$ SS48 centrifuge tube was placed below the tip and the DNA was eluted using $15 \mathrm{ml}$ of Buffer QF. A total of $10.5 \mathrm{ml}$ of chilled isopropanol was added and the mixture was incubated at $4^{\circ} \mathrm{C}$ for $30-60 \mathrm{~min}$. The mixture was centrifuged at $12000 \mathrm{rpm}$ for $40 \mathrm{~min}$ and the pellet obtained was washed with $5 \mathrm{ml}$ of $70 \%(\mathrm{v} / \mathrm{v})$ ethanol. The tube was centrifuged at $12000 \mathrm{rpm}$ for $10 \mathrm{~min}$ and the pellet DNA was air dried in a laminar flow. Finally, the DNA was dissolved in 1 $\mathrm{ml}$ of TE buffer (10 mM Tris, 1 mM EDTA; $\mathrm{pH} 8$ ).

The concentration and purity of the plasmid were determined using a spectrophotometer. The DNA yield ranged from 300 to $500 \mu \mathrm{g}$ per $100 \mathrm{ml}$ of overnight culture with good purity, i.e. A260/280 between 1.8-2.0 was obtained. The DNA quality was further verified by restriction enzyme digestion followed by electrophoresis on $1 \%$ agarose gels.

\section{DNA Microcarrier Preparation and Bombardment for PDS-1000/He Apparatus}

DNA precipitation onto gold microcarrier was carried out according to the manufacturer's instruction (Biolistics PDS/He 1000; Bio-Rad). Five $\mu \mathrm{l}\left(1 \mu \mathrm{g} \mu \mathrm{l}^{-1}\right)$ of plasmid DNA (either p35SCaMVsgfpS65T or pAHC25 for a single bombardment or combination of p35SCaMV-sgfpS65T and pAHC25 for co-bombardment), $50 \mu \mathrm{l}$ of $2.5 \mathrm{M} \mathrm{CaCl}_{2}$ and 20 $\mu 1$ of $0.1 \mathrm{M}$ spermidine were added sequentially to the $50 \mu \mathrm{l}$ gold microcarrier suspension. The mixture was vortexed for $3 \mathrm{~min}$, and spun for $10 \mathrm{~s}$ at room temperature. The supernatant was then discarded and the pellet washed with $0.25 \mathrm{ml}$ of absolute ethanol and followed by washing with $0.060 \mathrm{ml}$ of absolute ethanol. Six $\mu$ l of the solution were loaded onto the centre of the macrocarrier and was air dried.

Bombardments were carried out in a minimum of five replicates by using the following conditions; 1100 psi rupture disc pressure; $6 \mathrm{~mm}$ rupture disc 
to macrocarrier distance; $11 \mathrm{~mm}$ macrocarrier to stopping plate distance, $75 \mathrm{~mm}$ stopping plate to target tissue distance and $67.5 \mathrm{mmHg}$ vacuum pressure (Parveez et al., 1997; 1998). The bombarded tissues were then incubated at $28^{\circ} \mathrm{C}$ in the dark prior to GFP expression evaluation.

\section{Observation of GFP under Fluorescence Microscopy}

GFP fluorescence spots produced on bombarded oil palm calli were observed under a Leica MZ12.5 stereomicroscope which has been attached with a fluorescence GFP Plus filter module (Leica). Observation was carried out at several time intervals, i.e. every day for the first 14 days and followed by once a month. Autofluorescence was differentiated by comparing with non-bombarded tissues. A narrow bandpass interference filter (S550/100 NP) was used to minimise chlorophyll interference. Images of GFP-expressing cells were captured using a 4910 Series RS-170 and CCIR monochrome CCD camera (COHU, San Diego, CA) and analysed using Leica IM50 Image Manager. The images obtained were further processed and stored using Adobe Photoshop 3.0 software (Adobe System Incorporated, USA). The green level of the images was then analysed to quantify the green fluorescent intensity using Leica QWin Pro (Leica System, Germany).

\section{Isolation of Total Genomic DNA}

Transformed plantlets originated from single or co-bombardment were subjected to molecular analysis for confirmation of their transgenic status. DNA isolation was carried out using CTAB method (Doyle and Doyle, 1990) with some modifications. Samples were chilled and ground in liquid nitrogen. Once the samples were properly ground, $10 \mathrm{ml}$ CTAB extraction buffer (100 mM Tris- $\mathrm{HCl}, \mathrm{pH} 8.0 ; 20$ mM EDTA; $1.4 \mathrm{M} \mathrm{NaCl} ; 2 \%$ CTAB; $1 \%$ PVP, $0.2 \%$ 2-mercaptoethanol) were added. Samples were incubated at $65^{\circ} \mathrm{C}$ for $1 \mathrm{hr}$ followed by $20 \mathrm{~min}$ at room temperature. Two $\mathrm{ml}$ of chloroform: isoamylalcohol (24:1) were added and the samples were centrifuged at $4^{\circ} \mathrm{C}, 13000 \mathrm{rpm}$ for $5 \mathrm{~min}$. The aqueous phase was transferred into a new tube. Samples were extracted twice with $5 \mathrm{ml}$ chloroform:isoamyl alcohol (24:1). The DNA was precipitated by adding $6 \mathrm{ml}$ chilled isopropanol. After $20 \mathrm{~min}$ at room temperature, the samples were centrifuged at $13000 \mathrm{rpm}$ for $5 \mathrm{~min}$. Supernatant was discarded and the pellet was dried at room temperature. The pellet was washed with Washing Buffer [76\% (v/v) ethanol, $10 \mathrm{mM}$ ammonium acetate] and incubated at room temperature for $20 \mathrm{~min}$ before being centrifuged at $13000 \mathrm{rpm}$ for $5 \mathrm{~min}$. DNA pellet was dried and dissolved in $500 \mu \mathrm{l}$ TE buffer $(10 \mathrm{mM}$ Tris, $1 \mathrm{mM}$ EDTA; pH 7.5).

\section{Primers for Polymerase Chain Reaction (PCR)}

Primers used in this study are listed in Table 1. Primers for $g f p$ gene were designed using Vector NTI Suite 5 (InforMax, Inc). Primers for internal control were as described by Nurfahisza et al. (2014).

\section{PCR Analysis}

PCR amplifications were performed using a PTC- $100^{\mathrm{TM}}$ Programmable Thermal Controller (MJ Research, Inc.). PCR reaction was carried out in the following mixture: DNA (100 ng) + reaction buffer (containing $50 \mathrm{mM} \mathrm{KCl}$ and $10 \mathrm{mM}$ Tris-Cl; pH 9.0) + $8 \% \mathrm{MgSO}_{4}+\mathrm{dNTPs}(20 \mu \mathrm{M})+$ Taq DNA polymerase (Promega). The PCR cycle for amplification of internal control was as follows: 30 cycles with hot start at $95^{\circ} \mathrm{C}(5 \mathrm{~min})$, denature at $92^{\circ} \mathrm{C}(50 \mathrm{~s})$, annealing at $65^{\circ} \mathrm{C}(50 \mathrm{~s})$ and elongation at $72^{\circ} \mathrm{C}(60 \mathrm{~s})$ and finally $2 \mathrm{~min}$ at $72^{\circ} \mathrm{C}$ (Parveez, 1998). In parallel, the PCR cycle for screening the presence of $g f p$ gene was as follows: 30 cycles with hot start at $94^{\circ} \mathrm{C}(3$ min), denature at $94^{\circ} \mathrm{C}(30 \mathrm{~s})$, annealing at $68^{\circ} \mathrm{C}(60$ s) and elongation at $72^{\circ} \mathrm{C}(110 \mathrm{~s})$ and finally $5 \mathrm{~min}$ at $68^{\circ} \mathrm{C}$. Water and non-bombarded sample were used as negative controls and $20 \mathrm{ng}$ plasmid containing gfp gene was used as positive control.

\section{RESULTS AND DISCUSSION}

Embryogenic calli bombarded with p35SCaMVsgfpS65T construct showed a random distribution of green fluorescent spots when observed under blue illumination using the Leica MZ12.5 fluorescent

TABLE 1. PRIMERS AND THEIR RESPECTIVE SEQUENCES USED IN POLYMERASE CHAIN REACTION (PCR) ANALYSIS

\begin{tabular}{lllr}
\hline Primers & \multicolumn{1}{c}{ Sequences } & Gene & Expected fragment size \\
\hline PO12 & 5'-CCCTCATCCATAGCA CA- 3' & Internal & $1.1 \mathrm{~kb}$ \\
POR38 & 5'-CAGGGAGCAAAGAAGCA- 3' & Control & \\
PGFPF 1 & 5'-CCATGGTGAGCAAGGGCGAG-3' & \\
PGFPR 2 & 5'-GGGGTGTTCTGC TGGTAGTGGTCG-3' & sgfp & $568 \mathrm{bp}$ \\
\hline
\end{tabular}


microscope as compared to faint greenish background for the non-transformed calli (Figure 2). The untransformed calli and calli transformed with pAHC25 alone failed to show any green fluorescent spots. The p35SCaMV-sgfpS65T was chosen as this construct was shown to be the most efficient gfp plasmid that showed the highest fluorescent signals as well as the longest GFP expression as compared to 10 other plasmids carrying different version of the $g f p$ gene in combination with the use of different promoters (Majid and Parveez, 2007). The random distribution of $g f p$ expressing cells on the transformed embryogenic calli was due to the nature of microprojectile bombardment method which targets the genes randomly into the tissues. High intensity green fluorescent spots appeared as early as $16 \mathrm{hr}$ post bombardment when observed at 10X magnification. However, the size and intensity of fluorescent spots were varied. It is envisaged fluorescence of nucleus within the cell could be observed and individual fluorescence spots represent single fluorescent cell could be clearly visualized, respectively (Figures $3 b$ and $3 c$ ). It was also observed that at the same magnification (10X) and light setting, highly fluorescing calli detected at $16 \mathrm{hr}$ after bombardment failed to be detected three weeks after bombardment, indicating the reduction in the number of $g f p$ expressing cells (Figures $3 d$ and $3 e$ ). Similarly the number and fluorescence intensity reduces when compared at $16 \mathrm{hr}$ and after three weeks (Figures $3 b$ and $3 f$ ). In soyabean and walnut, it was reported that almost all the transiently GFP fluorescent spots disappeared after 7-10 days (Ponappaetal., 2000; Escobaret al.,2000). In sorghum, the fluorescent intensity reduced greatly after one week and majority of the green spots disappeared within one month (Jeoung et al., 2002). However, at a higher magnification (25X), few expressing $g f p$ cells
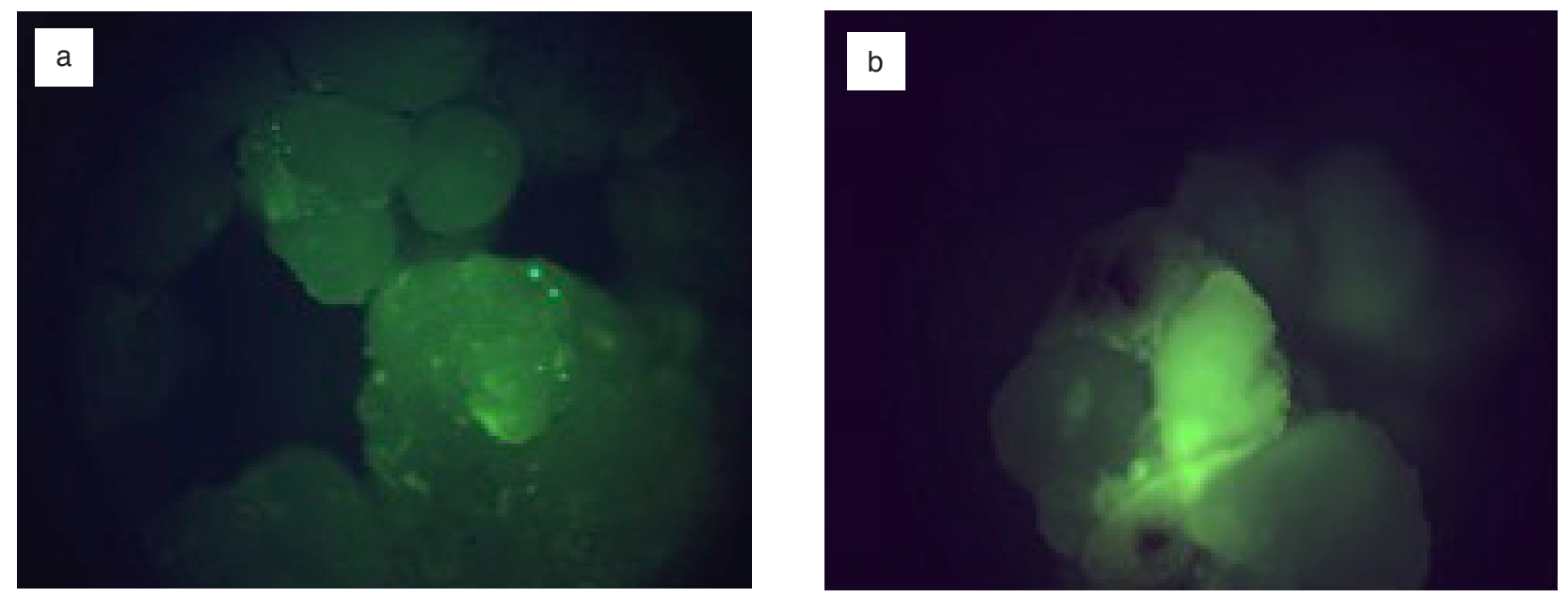

Figure 2. Visualisation of green fluorescent protein (GFP) spots oil palm embryogenic calli 16 hr after bombardment with (a) p35SCaMV-sgfpS65T and (b) pAHC25. 10X Magnification.

that these clearly $g f p$ expressing embryogenic calli could result in the proliferation of $g f p$ expressing cell clumps which could be easily distinguished, isolated and regenerated to produce transgenic oil palm plantlets that express $g f p$ in the entire plant cells.

\section{Plant Regeneration of GFP Expressing Embryogenic Calli}

The $g f p$ bombarded embryogenic calli were cultured on the EC medium for regeneration. It was observed that the $g f p$ expression could only be monitored closely for a maximum of three weeks post-bombardment (Figure 3). It was observed that at the lower magnification (10X) the green fluorescence looks like individual spots (Figure $3 a$ ). Later when the same bombarded calli was observed at higher magnifications, X25 and X100, brighter could be detected, indicating some reduction in the number of $g f p$ expressing cells and in the fluorescent intensity. It is well-known that in transformation process, after transgenes are transferred into a target cell, only a small percentage of the transgenes will be integrated into the nuclear genome. Thus, it would be expected that only a small number of $g f p$ genes were stably integrated and expressed, while non-integrated $g f p$ genes were degraded. The reduction may further become apparent since the signal amplification is not available because each gfp gene has only one chromophore (Zimmer, 2002). Therefore, since the oil palm cell multiplication time is slow and the $g f p$ gene in original cells loses its activity, no new transformed cells (with $g f p$ gene) will be observed. Besides, reduction in promoter activity and $g f p$ being shaded by other proteins could also contribute to the reduction in detectable GFP signal (Múller et al., 2001). Similar observation 

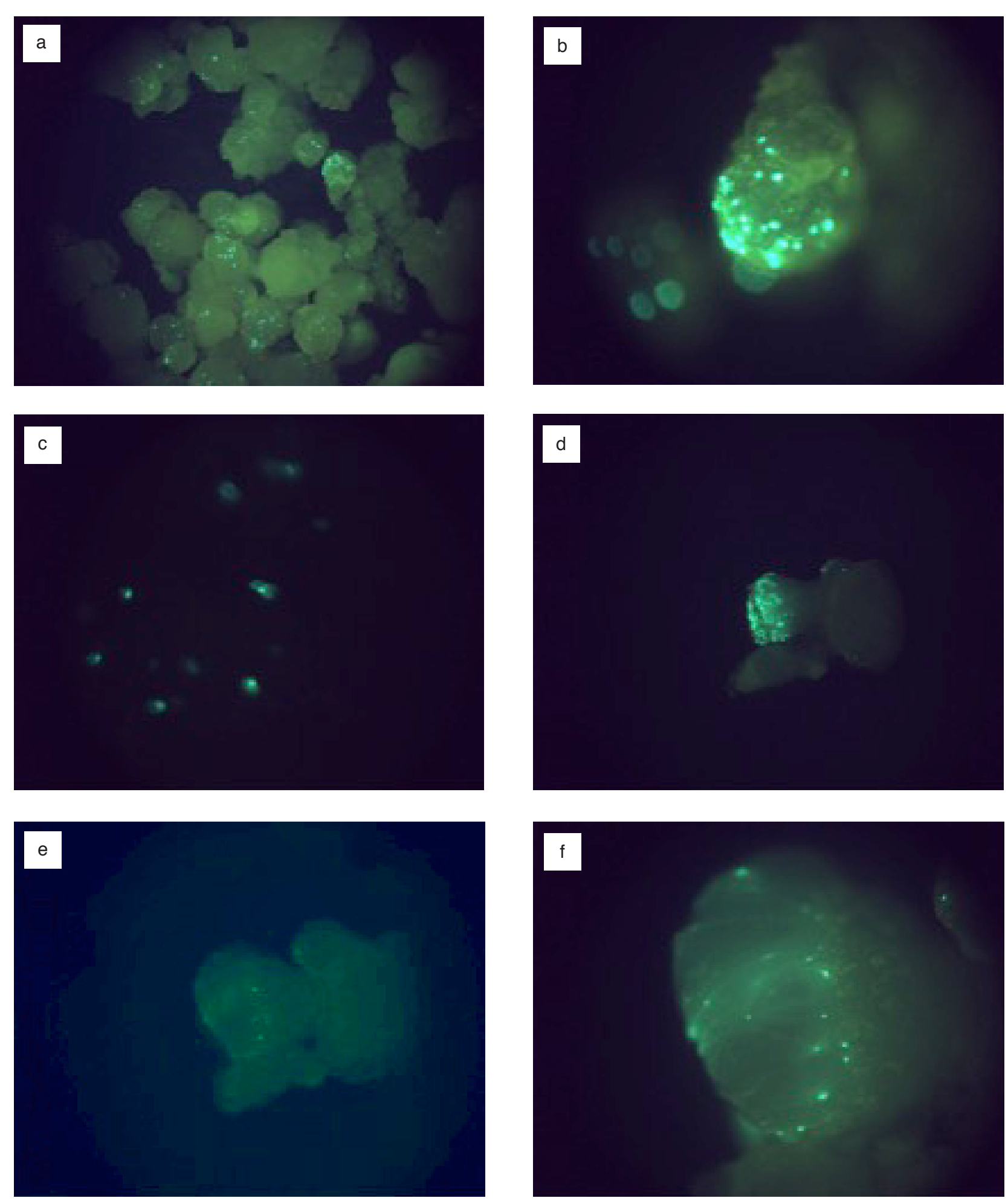

Figure 3. Visualisation of green fluorescent protein (GFP) spots on oil palm calli after bombardment with p35SCaMV-sgfpS65T. (a) After $24 \mathrm{hr}$ at $10 \mathrm{X}$ magnification, (b) 25X magnification and (c) 100X magnification. (d and e) Same sample but at 16 hr and three weeks after bombardment, respectively. (f) Same as (b) but three weeks after bombardment.

was also reported in several other systems, such as wheat (Huber et al., 2002) and orchid (Tee et al., 2003). In litchi, it was reported that GFP signal could not be seen as GFP activities were embedded in the cells and became diffused (Puchooa, 2004).
For the first three to four weeks duration, the increase in callus size was observed, indicating the occurrence of cell division. Due to multi-directional division of callus cells, consisting of transformed as well as majority of non-transformed cells, shrinkage 
of fluorescent cell mass was expected. The multidirectional cell division could lead to diffusion of green fluorescence while the transiently expressing gfp gene cells lost the expression. As a result, reduced number of GFP expressing cells were detected leading to the reduction in GFP signal detected during this period. However, at this time, the presence of several brighter green fluorescent spots within a single green fluorescent patch could be clearly distinguished (Figure 4). These green fluorescent spots were not detected within seven days after bombardment. When the images were analysed using Leica Qwin Professional Programme, the presence of two or several green fluorescent spots were confirmed, showing the presence of two or more green level peaks. This is in agreement with the report that the doubling time of oil palm tissue culture is about 10-30 days depending on various factors such as clone and media used (Tarmizi et al., 2003). This is based on the observation that oil palm suspension culture showed one-fold to three-fold increments in the mass within a month, suggesting oil palm cells double once to twice a month. Therefore, these images probably suggest that some
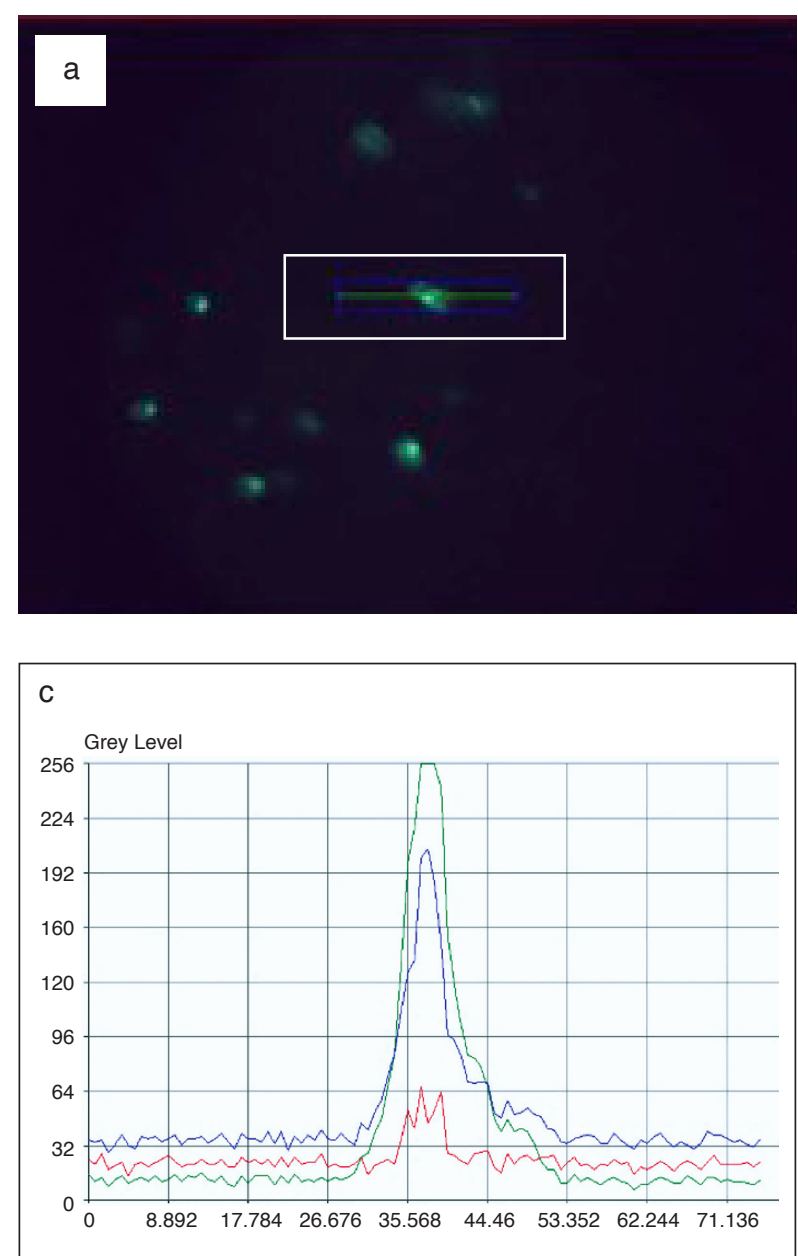

of the gfp transformed cells could have actually divided a few times after bombardment resulting in the formation of few linked $g f p$ expressing cells. This observation, if consistent, suggests that GFP could practically be used as a selection system for oil palm without hampering cell division.

During the regeneration process, it was expected that cells with stably expressed $g f p$ gene would double and produce sectors of $g f p$ expressing cells. A GFP sector refers to a mass of tissues derived from a dividing transformed cell, and it represents a stable transformation event. After reaching a reasonable size, the GFP sector could be isolated and regenerated to produce complete plantlets expressing $g f p$. This procedure was successfully used and reported in barley, oat, rose and grape (Ahlandsberg et al., 1999; Kaeppler et al., 2000; Kim et al., 2004; Dhekney et al., 2007). In this experiment, within five months postbombardment, the formation of GFP sectors was observed in a few callus clumps (Figure 5a). The intense GFP sectors could be visually distinguished from the low autofluorescence background. It was also observed that some parts of the GFP sectors appeared brighter, which could be due to a higher
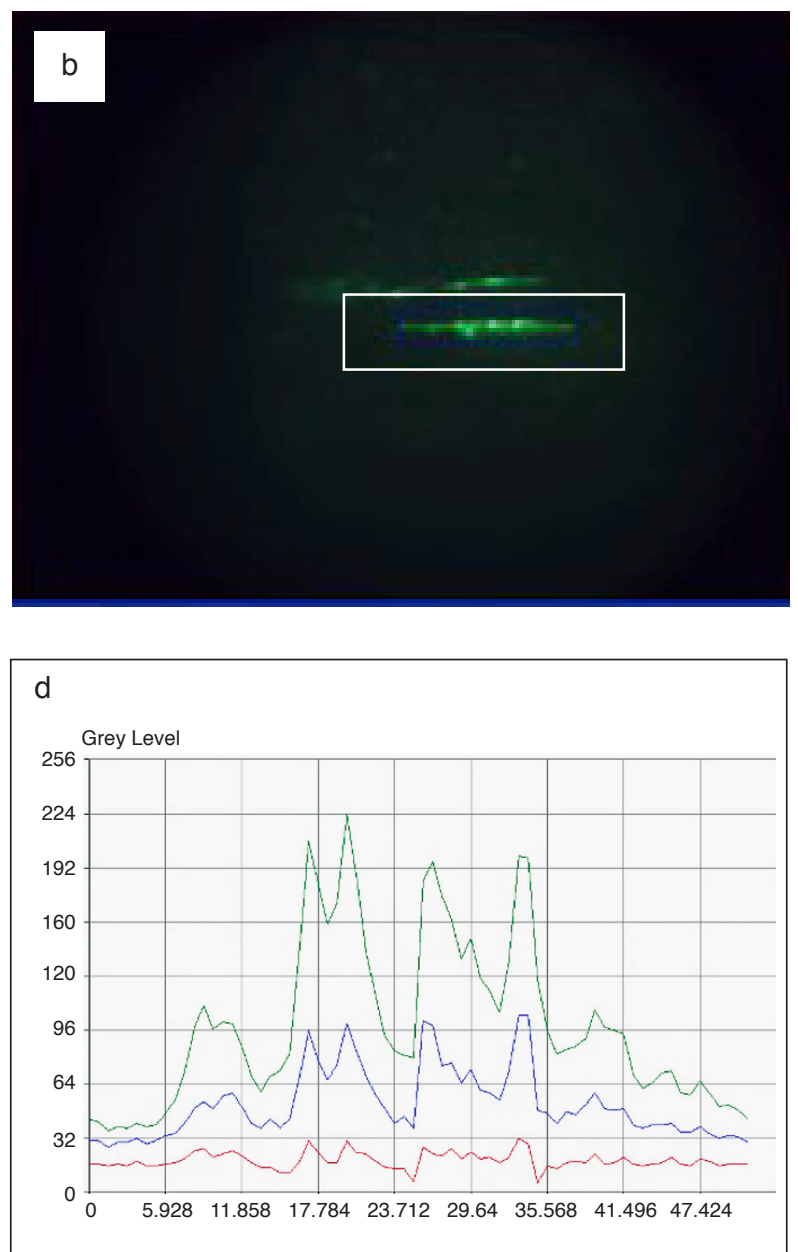

Figure 4. Identification of green fluorescent protein (GFP) expressing cells number using Leica Qwin Professional Programme. (a and c) One GFP expressing cell and ( $b$ and d) more than two GFP expressing cells. 
accumulation of GFP within the cells compared to diffused green surrounding cells. Furthermore, results presented in Figure 5a could also suggest that some of the $g f p$ transformed cells actually divided a few times after bombardment and thereby formed a few linked $g f p$ expressing cells. Comparatively, sugar-cane, an annual crop, which exhibits celldoubling time of every two days, could produce a sector of about $0.8 \mu \mathrm{m}$ in size within three months post-bombardment (Elliot et al., 1998).

As the plant regeneration progressed and the GFP sectors were not individually isolated, the signals obtained could not be tracked down any longer due to the high autofluorescence, which increasingly and potentially masked the GFP fluorescent areas. This autofluorescence could be seen in embryoids and other plantlet parts (Figures $5 b$ to $5 d$ ). The GFP expressing embryoids demonstrated a yellowish white fluorescence due to GFP-like autofluorescence. In addition, plantlet parts, such as base, wounded tissues, dead tissue and contaminated cells may also exhibit green autofluorescence, which made it more difficult to distinguish the real GFP fluorescence. Therefore, during the developmental stage, when GFP intensity reduces, monitoring of $g f p$ expressing cells could not be carried out effectively due to autofluorescence. This problem is not uncommon as there are many reports demonstrating the presence of autofluorescence in other plants such as rice, maize, petunia and soyabean (Vain et al., 2000; Geest and Petolino, 1998; Garabagi and Strommer, 2000; Ponappa et al., 2000). Low expressing GFP cells are difficult to be identified in the presence of autofluorescence and these problems worsen in lignified cells (Santi et al., 2003). Nevertheless, in the presence of autofluorescence, $g f p$ expression was enhanced around five-fold by changing the $\mathrm{pH}$ of media from 5.5 to 7.5 for Arabidopsis and tobacco (Wu et al., 2011).

During plantlet regeneration from embryoids, gfp expression could be observed on different parts of the plantlets such as in base, root and leaf (Figures $6 c$ to 6 f). The leaf primordia that are rich in chlorophyll
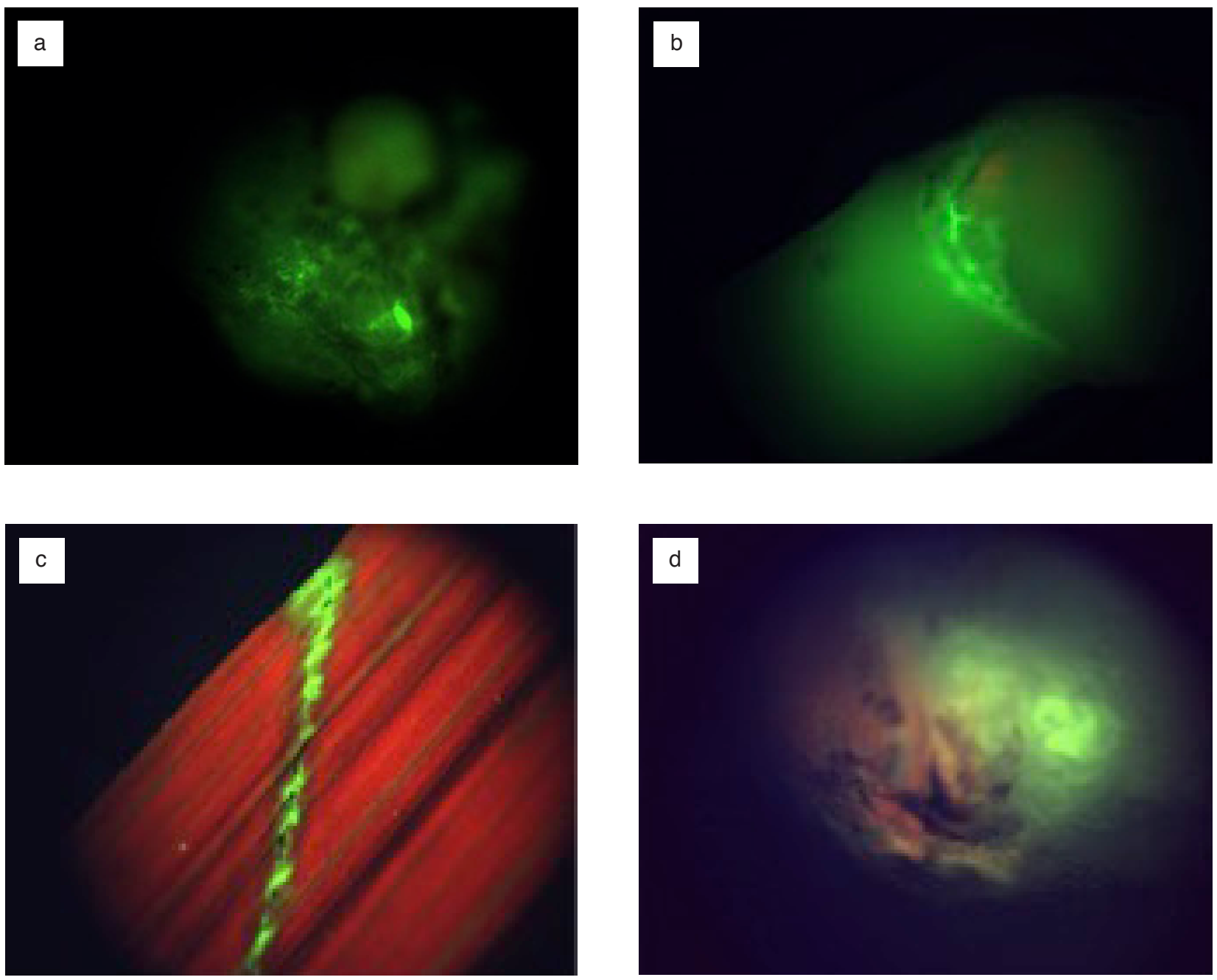

Figure 5. Visualisation of genuine green fluorescent protein (GFP) sectors on transformed embryogenic calli (a). Endogenous green autofluorescence are also observed on oil palm plantlet base (b), injured leaf (c) and embryoid (d). 

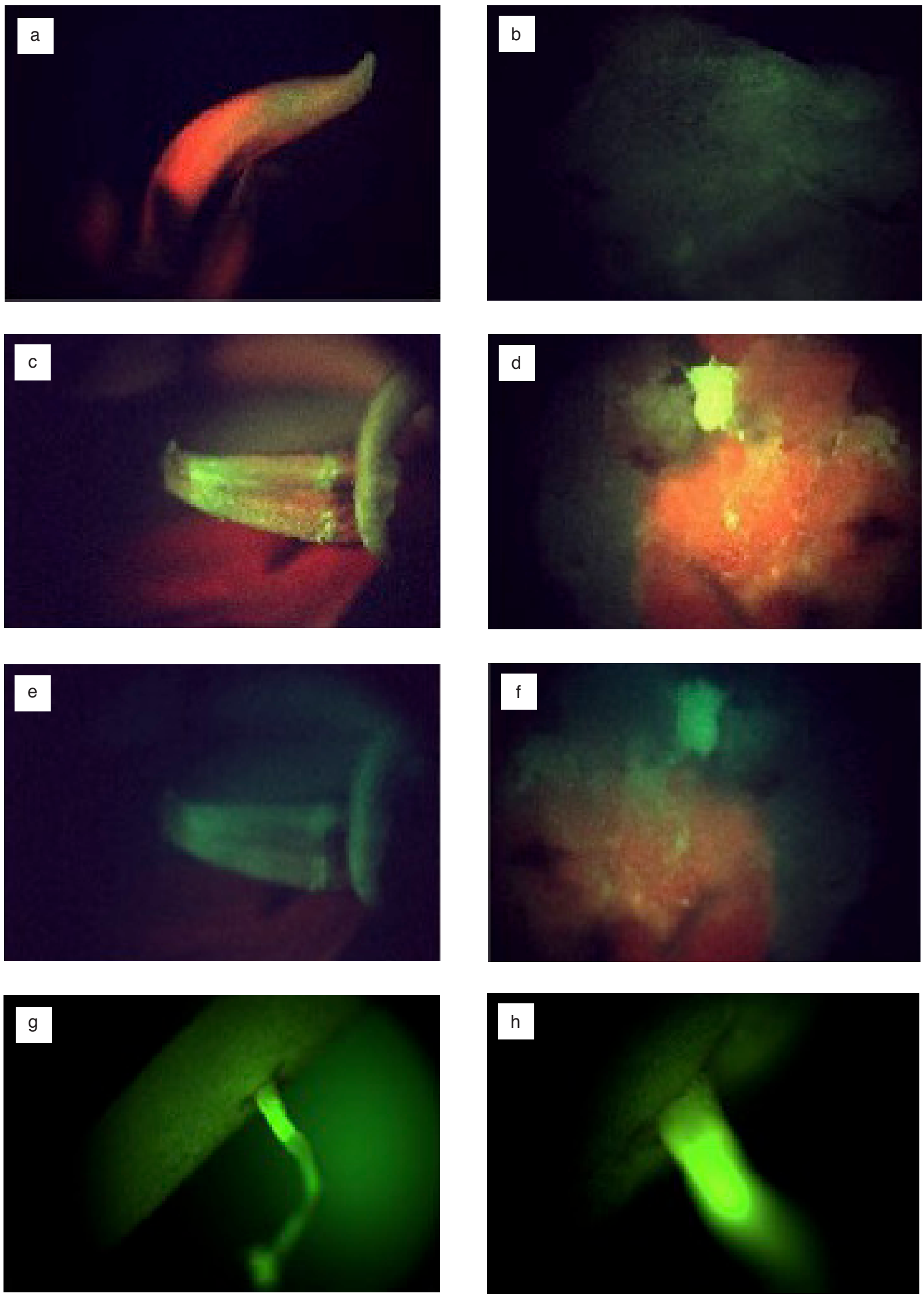

Figure 6. Visualisation of green fluorescent protein (GFP) in different parts of oil palm transformed plantlet. Red autofluorescence could be seen on both untransformed ( $a$ and $b$ ) and transformed ( $c$ and $d$ ) leaf primordia (magnification: 16X) and plantlet base (magnification: 32X), respectively. Clearer GFP could be seen after elimination of chlorophyll using a cutoff filter on transformed leaf primordia (e) and plantlet base (f). No red autoflorescence was observed on transformed roots ( $g$ and $h$ ). Magnification: $32 X$. 
appeared yellowish green. However, when a tailor made band-pass filter (Leica, Germany) which could cut the chlorophyll's red fluorescent was used, the leaf primordia became green fluorescent. Green fluorescence was also detected in the root of transformed plantlet but not in the non-transformed plantlet (Figures $6 g$ and $6 h$ ). GFP detection in root was relatively easier since the tissue was lacked of chlorophyll and therefore appeared green (no red fluorescence). These $g f p$ expressions detected after using the filter could have originated from earlier transformation events. Therefore, although the expression could not be detected consistently during the plantlet development, it could be postulated that gfp could be stably transformed in oil palm calli. It was reported in Medicago truncatula (Kamate et al., 2000), that $g f p$ expression ceased at the initiation of embryo development but was later observed in the vascular tissue of floral organs and roots of the plant obtained. This observation was probably due to the fact that $g f p$ was transiently expressed at the early stage of the development but the stable integration of $g f p$ gene into the plant genome occurred at the later stage of regeneration. The stably transformed cells then started to form a critical mass of tissue available for signal detection during the differentiation process. Further analysis of the transgenic plants confirmed the stable integration of the $g f p$ gene into the genome.

Green autofluorescence was observed both in the leaf vein of transformed and untransformed oil palm plantlet (data not shown). But the green fluorescence in vein of transformed leaf was more intense and yellowish compared to untransformed leaf. This indicates that GFP may have been accumulated in the leaf-vein of transformed plantlet. It must be clarified here that the autofluorescence was observed on four oil palm leaf and not on the three leaf, indicating that autofluorescence expression is higher in older leaves. Similarly, higher autofluorescence in vascular bundle of mature leaf compared to those of young leaf, was reported in other plant systems (Benfey and Chua, 1990; Chytilova et al., 1999). However, contradictory observation was reported in tobacco leaf (Mitsuhara et al., 1996).

Overall observation revealed that cells expressing $g f p$ were found only in certain parts of the plantlets and not in the whole plantlet. Possible reason for the inconsistent $g f p$ expression observed in this study is due to the absence of herbicide or antibiotics selection during the regeneration process. It could also be due to the fact that the isolation of $g f p$ expressing callus was not carried out at the initial stage of the proliferation and regeneration. Without selection, cell growth competition between transformed and majority of untransformed cells occurred and resulted in the production of chimeric plants. Furthermore, some of the transformed cells could possibly be located in the inner part of the tissues, which made it difficult to be detected. Similar inconsistent $g f p$ expression in cotton plants was reported in the absence of selection pressure (Sunilkumar and Rathore, 2001). In sorghum, it was reported that not all GFP expressing callus sectors regenerated into whole plants even after several months (Jeoung et al., 2002).

\section{Plant Regeneration of GFP Expressing Embryogenic Calli Selected on Basta Medium}

Earlier experiments demonstrated inconsistent observation of $g f p$ expression cells during plant regeneration and only small sectors of cells expressing $g f p$ gene were obtained. The possible reason for this observation was that no separation or isolation of transformed cells from untransformed cells was carried out. In order to produce transgenic plantlets expressing $g f p$ in the whole plant, the following experiment was carried out: co-bombardment of the embryogenic calli with gfp gene and herbicide Basta resistant (bar) gene (pAHC25). Then, transformants were selected on medium containing Basta and subsequently used to regenerate transgenic plant. By doing this, it is hoped that transformants, which carry both genes, will regenerate and express $g f p$ in the whole plant.

Embryogenic calli were co-bombarded with p35SCaMV-sgfpS65T and pAHC25 plasmids and $g f p$ expressing cells were occasionally observed under blue light. One week after bombardment, the embryogenic calli were transferred onto fresh medium containing $50 \mathrm{ug} \mathrm{ml}^{-1}$ of Basta (Parveez et al., 2007). GFP expressing cells were observed up to five months after bombardment (Figure 7). However, no $g f p$ expressing cell sectors were obtained. After seven months of culture on medium containing Basta, resistant embryogenic calli were obtained. The Basta-resistant embryogenic colonies were allowed to proliferate until the size was big enough to be individually isolated and used for regeneration. However, it was observed that none of the resistant colonies showed any green fluorescence. Similarly, when plantlets regenerated from those resistant colonies were obtained and screened for GFP under fluorescent microscope, no signal was detected. This is not expected as the transgenic plants were regenerated on medium containing Basta and cotransformed with two constructs each carrying either the bar or gfp genes. Similar observation was reported for litchi, in which no GFP glowing plants were obtained after selection on kanamycin and all GFP activities were embedded in the cells looked blurred (Puchooa, 2004). In contrast, stable GFP sector was recovered after kanamycin selection for soyabean, canola, Medicago truncatula and rice, (Larkin and Finer, 2000; Cardoza and Stewart, 2003; Chabaud et al., 2003; Moghaib, 2010). 

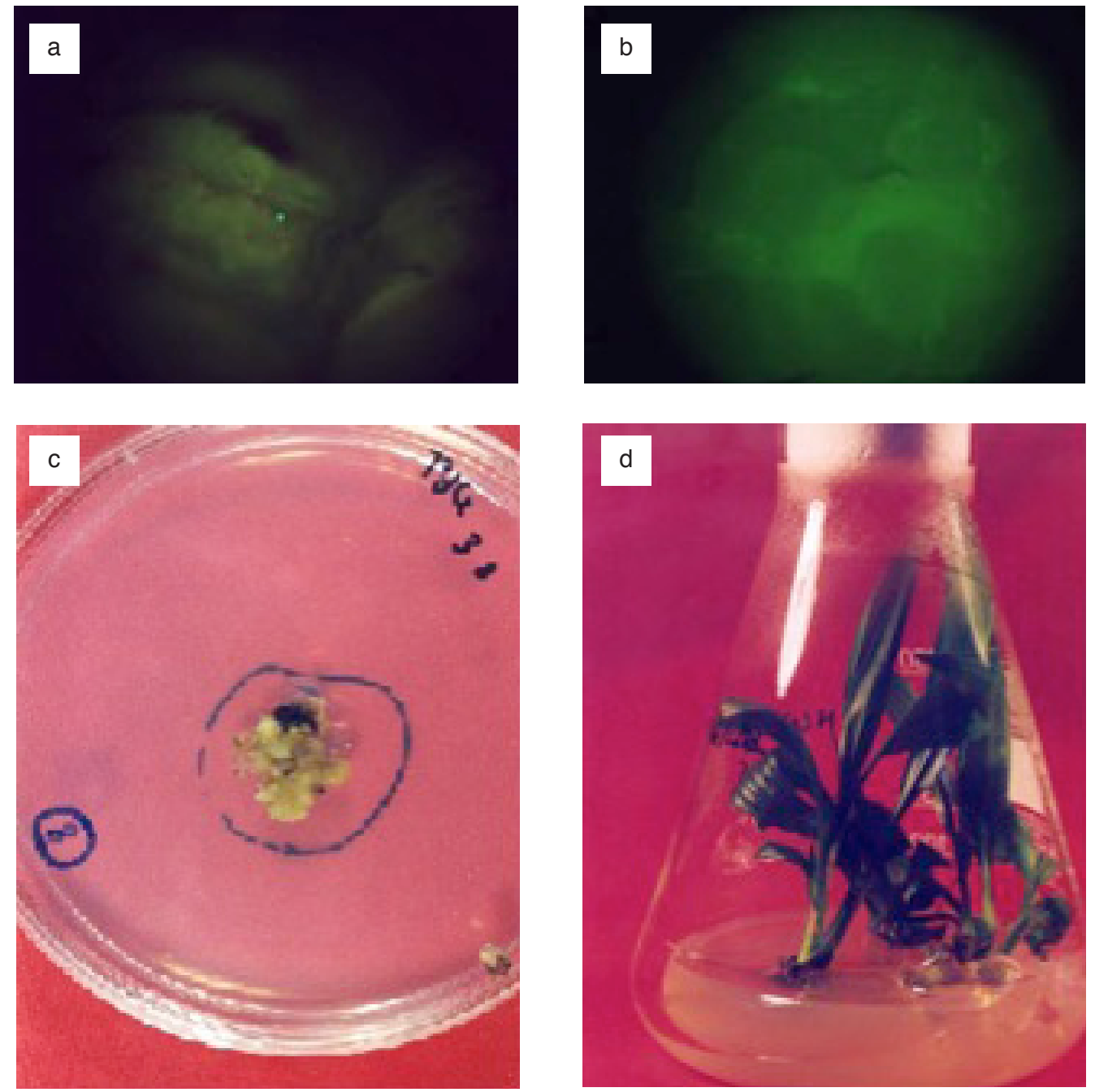

Figure 7. Regeneration of oil palm embryogenic calli on Basta selection after bombardment with bar gfp gene construct. Green fluorescent protein (GFP) spot on bombarded calli (a) and untransformed calli (b), magnification 25X. Basta-resistant calli (c) and putative Basta-resistant plantlets (d).

\section{Molecular Analysis of Transgenic Plants}

GFP signals detected in the calli, embryoids and parts of the regenerated plantlet were only observed for the first transformation experiment which was performed without the selectable marker gene. These observations provide an initial evidence of stably transformed gfp gene into oil palm cells. To confirm the integration of $g f p$ gene in oil palm genome, molecular analysis was carried out. PCR analysis was performed on total genomic DNA extracted from plantlets regenerated from the second experiment in which the transformants were selected on medium containing Basta. Genomic DNA samples were initially subjected to PCR amplification using an oil palm internal control primer set, POR12 and POR38 (Nurfahisza et al., 2014). The primers were expected to produce a 1.1 $\mathrm{kb}$ band. The internal control was to ensure the suitability of DNA samples for PCR amplification. If the amount or purity of the DNA is not suitable for
PCR amplification, there will be no DNA fragment amplified.

A total of 16 samples successfully produced the $1.1 \mathrm{~kb}$ of oil palm internal control fragment (data not shown). These positive DNA samples were later subjected to PCR amplification using primers specific for $g f p$ gene. Results showed that 10 out of 16 samples were able to amplify the $568 \mathrm{bp} g f p$ gene fragment (Figure 8). Similar results were also obtained when PCR for the bar gene, used for selection, was carried out (data not shown). The results showed that around two-third of the samples demonstrated the presence of the $g f p$ gene even though most of them did not show any GFP signal when observed under blue light prior to the extraction of their genomic DNA. This is probably due to the fact that the number of GFP expressing cells is insufficient for detection as compared to the highly sensitive PCR analysis. For PCR analysis, only a single copy of the $g f p$ gene is required to provide a positive result. The above observation demonstrated the presence of $g f p$ 
gene in oil palm genome even though no expression of the $g f p$ gene was observed. Similar result was reported in Anthurium in which only 11 out of 22 plants regenerated showed positive PCR for the $g f p$ gene and only seven of them expressed GFP in young calli and stems (Zhao et al., 2010). It was suggested that the lack of protein expression resulted in no full GFP expression. This could be due to either gene silencing as a consequence of methylation of promoter region or multiple insertion (Zhao et al., 2010).

\section{CONCLUSION AND FUTURE STUDIES}

Transgenic oil palm plantlets were successfully generated after bombardment with either the $g f p$ gene alone or in combination with the bar gene. However, the regenerated plantlets failed to show green fluorescence in the whole plantlets. The actual reason(s) for the failure to regenerate transgenic oil palm expressing GFP in the whole plant is not known, however, there are few possible reasons as modifications of GFP have been reported, such as increased fluorescent signal and solubility, varied emission spectrum and targeted to subcellular compartments. Those modifications have widened the applications of GFP as reviewed by Zimmer (2002). It is therefore proposed that for future studies, transformation of organelle targeted $g f p$ gene into oil palm embryogenic calli to be carried out for possible elimination of the above problem.

\section{ACKNOWLEDGEMENT}

The authors thank the Director-General of MPOB for permission to publish this article. Thanks are also due to Dr Jen Sheen, Massachusetts General Hospital, Boston, USA for providing p35SCaMVsgfpS65T plasmid, and the personnel in the Transgenic Technology Group of MPOB for their technical assistance. Special thanks to Dr Abdul Masani Mat Yunus and Dr Omar Abdul Rasid of MPOB for critically reviewing this article. This research is partly funded by the Ministry of

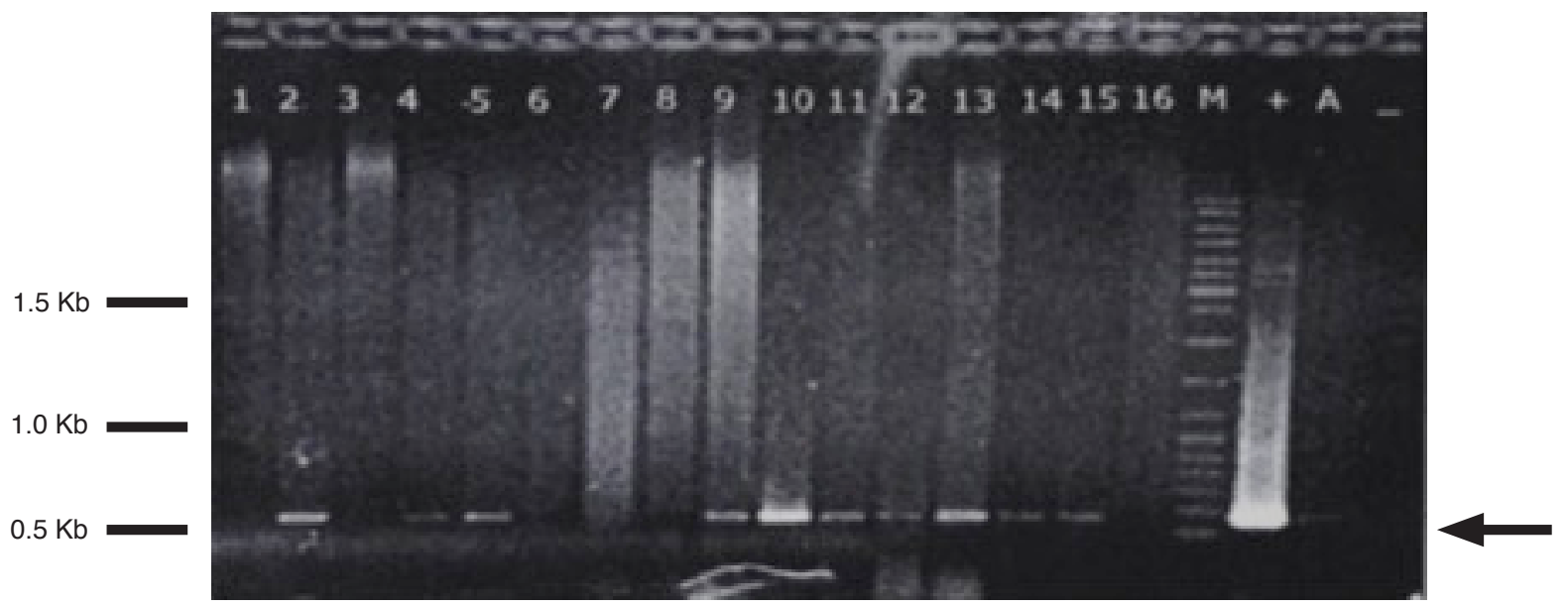

Figure 8. Polymerase chain reaction (PCR) analysis of genomic DNA from putative green fluorescent protein (GFP)-transformed plantlets. Lane 1-16; samples, M; GeneRuler DNA Ladder Mix (ThermoScientific), (-); water, A: untransformed samples, (+); p35SCaMV-sgfpS65T (positive control).The arrow shows the position of amplified sgfpS65T.

demonstrated in other plant system. One possible reason is that the GFP may be toxic to the oil palm cells. High-level of GFP has been shown to interfere with plant regeneration as demonstrated in maize protoplast (Sheen et al., 1995), Arabidopsis cells (Haseloff et al., 1997) and barley (Murray et al., 2004). Toxicity was suggested to be due to the production of fluorescent-related free radicals in nucleoplasm, as no toxicity effect was observed in the endoplasmic reticulum targeted GFP transformation. In addition, localisation of GFP within the endomembrane system and proplastids, was believed to aid the post-translational maturation of GFP and eliminate the toxicity (Haseloff et al., 1997). Since then, various
Science, Technology and Innovation, Malaysia under the Malaysia-MIT Biotechnology Partnership Programme (1999-2005).

\section{REFERENCES}

AHLANDSBERG, S; SATHISH, P; SUN, C and JANSSON, C (1999). Green fluorescent protein as a reporter system in the transformation of barley cultivars. Physiol. Plant, 107: 194-200.

BAHARIAH, B; PARVEEZ, G K A and KHALID, N (2012). Determination of optimal 
concentration of mannose as a selection agent for selecting transformed oil palm cells using the phosphomannose isomerase ( $p m i)$ gene as the positive selectable marker. J. Oil Palm Res. Vol. 24: 1250-1259.

BAHARIAH, B; PARVEEZ, G K A; MASANI, M Y A; MASURA, S S; KHALID, N and OTHMAN, R Y (2013). Biolistic transformation of oil palm using the phosphomannose isomerase ( $p m i)$ gene as a positive selectable marker. Biocatal. Agric. Biotechnol., 2: 295304. DOI: 10.1016/j.bcab.2013.08.004.

BENFEY, PN and CHUA, NH(1990). The cauliflower mosaic virus $35 S$ promoter: combinatorial regulation of transcription in plants. Science, 250: 959-966.

CARDOZA, V and STEWART, C N (2003) Increased Agrobacterium-mediated transformation and rooting efficiencies in canola (Brassica napus L.) from hypocotyl segment explants. Plant Cell Rep., 21: 599604.

CHABAUD, M; DE CARVALHO-NIEBEL, F and BARKER, D G (2003). Efficient transformation of Medicago truncatula cv. Jemalong using he hypervirulent Agrobacterium tumefaciens strain AGL1. Plant Cell Rep., 22: 46-51.

CHALFIE, M TU; Y EUSKIRCHEN, G; WARD, W W and PRASHER, D C (1994). Green fluorescent protein as a marker for gene expression. Science, 263: 802-805.

CHRISTIENSEN, A H; SHARROCK, $\mathrm{R} A$ and QUAIL, P H (1992). Maize polyubiquitine genes: thermal perturbation of expression and transcript splicing, and promoter activity following transfer to protoplast by electroporation. Plant Mol. Biol. 18: 675-689.

CHYTILOVA, E, MACAS, J and GALBRAITH, D W (1999). Green fluorescent protein targeted to the nucleus, a transgenic phenotype useful on studies in plant biology. Annals of Botany, 83: 645-654.

DHEKNEY, S A; LI, Z T; AN AMAN, M; DUTT, M; TATTERSALL, J and GRAY, D J (2007). Genetic transformation of embryogenic cultures and recovery of transgenic plants in Vitis vinifera, Vitis rotundifolia and Vitis hybrids. Acta Hort., 738: 743-748.

DOYLE, J J and DOYLE, J L (1990). Isolation of plant DNA from fresh tissue. Focus 12: 13-15.

EEUWENS, C J (1976). Mineral requirement for growth and callus initiation of tissue explants from mature coconut palms (Cocos nucifera) cultured in vitro. Physiol. Plant., 36: 23-28.
ELLIOT, A R; CAMBELL, J A; BRETTELL, R I S and GROF, C P L (1998). Agrobacterium-mediated transformation of sugarcane using GFP as a screenable marker. Aust. J. Plant Physiol., 25: 739743.

ELLIOT, A R; CAMBELL, J A; BRETTELL, R I S and GROF, C P L (1999). Green fluorescent protein facilitates rapid in vivo detection of genetically transformed plant cells. Plant Cell Rep., 18: 707-714.

ESCOBAR, M A; PARK, J I; POLITO, V S; LESLIE, C A; URATSU, S L; MCGRANAHAN, G H and DANDEKAR, A M (2000). Using GFP as a scoreable marker in walnut somatic embryo transformation. Annals of Botany, 85: 831-835.

GARABAGI, F and STROMMER J (2000). Green fluorescent protein as an all-purpose reporter in Petunia. Plant Mol Biol, 18: 219-226.

GEEST AHM VAN DER and PETOLINO, J F (1998). Expression of a modified green fluorescent protein gene in transgenic maize plants and progeny. Plant Cell Rep., 17: 760-764.

HASELOFF, J; SEMERING, K R; PRASHER, D and HODGE, S (1997). Removal of a cryptic intron and subcellular localization of green fluorescent protein are required to mark transgenic Arabidopsis plants brightly. Proc. of the National Academy of Science USA, 94: 2122-2127.

HEIM, R; PRASHER, D C and TSIEN, R Y (1994). Wavelength mutation and post-translational modification of green fluorescent protein. Proc. of the National Academy of Science USA, 91: 12501-12504.

HERNANDEZ-GARCIA, C M; BOUCHARD, R A; RUSHTON, P J; JONES, M J; CHEN, X; TIMKO, M P and FINER, J J (2010). High level transgenic expression of soybean (Glycine max) GmERF and Gmubi gene promoters isolated by a novel promoter analysis pipeline. BMC Plant Biology, 10: 237.

HTWE, HN; LING, H C;ZAMAN, FQ and MAZIAH, $M$ (2014). Plant genetic transformation efficiency of selected Malaysian rice based on selectable marker Gene (hptII). Pakistan J. Biol. Sci., 17: 472-481.

HUBER, M; HAHN, R and HESS, D (2002). High transformation frequencies obtained from a commercial wheat (Triticum aestivum L. cv. 'Combi') by microbombardment of immature embryos followed by GFP screening combined with PPT selection. Mol Breed, 10: 19-30.

IGNACIMUTHU, S and CEASAR, S A (2012). Development of transgenic finger millet [(Eleusine 
coracana (L.) Gaertn]. resistant to leaf blast disease. J. Biosci. 37: 135-147.

IZAWATI, A M D; MASANI, M Y A; ISMANIZAN, I and PARVEEZ, G K A (2015). Evaluation on the effectiveness of 2-deoxyglucose-6-phosphate phosphatase (DOGR1) gene as a selectable marker for oil palm (Elaeis guineensis Jacq.) embryogenic calli transformation mediated by Agrobacterium tumefaciens. Front. Plant Sci. 6:727. DOI: 10.3389/ fpls.2015.00727.

JAMES, C (2015). Global status of commercialized biotech/GM crops: 2015. ISAAA Brief No. 51. Ithaca, NY, USA: ISAAA.

JEOUNG, J M; KRISHNAVENI, S; MUTHUKRISHNAN, S; TRICK, H N and LIANG, G H (2002). Optimization of sorghum transformation parameters using genes for green fluorescent protein and glucuronidase as visual markers. Hereditas, 137: 20-28.

JOERSBO, M; DONALDSON, I; KREIBERG, J; PETERSEN, S G; BRUNSTEDT, J and OKKELS, F T (1998). Analysis of mannose selection used for transformation of sugar beet. Mol. Breed., 4: 111-117.

KAMATE, K; RODRIQUEZ-LLORENTE, D; SCHOLTE, M; DURAND, P; RATET, P; KONDOROSI, E; KONDOROSI, A and TRINH, T H (2000). Transformation of floral organs with GFP in Medicago truncatula. Plant Cell Rep., 19: 647-653.

KAEPPLER, H F; MENON, G K; SKADSEN, R W; NUUTILA, A M and CARLSON, A R (2000). Transgenic oat plants via visual selection of cell expressing green fluorescent protein. Plant Cell Rep.,19: 661-666.

KIM, C K; CHUNG, J D; PARK, S H; BURRELL, A M; KAMO, K K and BYRNE, D H (2004). Agrobacterium tumefaciens-mediated transformation of Rosa hybrida using the green fluorescent protein (GFP) gene. Plant Cell Tissue Organ Culture, 78: 107-111.

KUNZE, I; EBNETH, M; HEIM, U; GEIGER, M; SONNEWALD, U and HERBERS, K (2001). 2-Deoxyglucose resistance: a novel selection marker for plant transformation. Mol. Breed., 7: 221-227.

LARKIN, K M and FINER, J J (2000). Sonicatedassisted Agrobacterium-mediated transformation of embryogenic soybean tissue and subsequent monitoring of gene expression with GFP. In vitro Cell Dev. Biol, 36: 64A.

LAY, F T; POON, S; MCKENNA, J A; CONNELLY, A A; BARBETA, B L; MCGINNESS, B S; FOX, J L; DALY,
N L; CRAIK, D J; HEATH, R L and ANDERSON, M A (2014). The C-terminal propeptide of a plant defensin confers functions. BMC Plant Biology, 14: 41.

MAJID, N A and PARVEEZ, G KA (2007). Evaluation of green fluorescence protein (GFP) as a selectable marker for oil palm transformation via transient expression. Asia Pac J Mol Bio Biotech, 15: 1-8.

MASANI, M Y A; NOLL, G A; PARVEEZ, G K A; SAMBANTHAMURTHI, R and PRÜFER, D (2014). Efficient transformation of oil palm protoplasts by PEG-mediated transfection and DNA microinjection. PLoS ONE 9: e96831. DOI:10.1371/ journal.pone.0096831.

MASLI, D I A; PARVEEZ, G K A and ISMAIL, I (2012). Optimisation of 2-deoxyglucose concentration for identifying the sensitivity level for oil palm embryogenic calli. J. Oil Palm Res. Vol. 24: 1296-1302.

MASLI, D I A; PARVEEZ, G K A and YUNUS, A M M (2009). Transformation of oil palm using Agrobacterium tumefaciens. J. Oil Palm Res. Vol. 21: 643-652.

MITSUHARA, I; UGAKI, M; HIROCHIKA, H; OHSHIMA, M; MURAKAMI, T; GOTOH, Y; KATAYOSE, Y; NAKAMURA, S HONKURA, R; NISHIMIYA, S; UENO, K; MOCHIZUKI, A; TANIMOTO, H; TSUGAWA, H; OTSUKI, Y and OHASHI, Y (1996). Efficient promoter cassettes for enhanced promoter foreign genes in dicotyledonous and monocotyledonous plants. Plant Cell Physiol., 37: 49-59.

MOGHAIEB, R E A (2010) Transgenic rice plants expressing cry1Ia5 gene are resistant to stem borer (Chilo agamemnon). GM Crops, 1: 288-293.

MULLER, W G; WALKER, D; HAGER, G L and MCNALLY, J G (2001). Large-scale chromatin decondensation and recondensation regulated by transcription from a natural promoter. J. Cell Biol., 154: 33-48.

MURASHIGE, T and SKOOG, F (1962). A revised medium for rapid growth and bioassays with tobacco tissue cultures. Physiol. Plant, 15: 473-497.

MURRAY, F; BRETTELL, R; MATTHEWS, P; BISHOP, D and JACOBSEN, J (2004). Comparison of Agrobacterium-mediated transformation of four barley cultivars using the GFP and GUS reporter genes. Plant Cell Reports, 22: 397-402

MUBMANN, V; SEREK, M and WINKELMANN, T (2011). Selection of transgenic Petunia plants using 
the green fluorescent protein (GFP). Plant Cell Tissue Organ Culture: 483-492 DOI: 10.1007/s11240-0119998-3.

NAGY, B; MAJER, P; MIHÁLY, R; DUDITS, D and HORVÁTH, G V (2011). Transient and transgenic approaches for functional testing of candidate genes in barley. Acta Biologica Szegediensis., 55: 129-133.

NAKAMURA, T and ISHIKAWA, M (2006). Transformation of suspension cultures of bromegrass (Bromus inermis) by Agrobacterium tumefaciens. Plant Cell, Tissue and Organ Culture, 84: 293-299.

NURFAHISZA, A R; RAFIQAH, M A; MASANI, MY A; HANIN, A N; RASID, O A; PARVEEZ, G K A and ISMAIL, I (2014). Molecular analysis of transgenic oil palm to detect the presence of transgenes. J. Oil Palm Res. Vol. 26: 96-103.

PARVEEZ, G K A; CHOWDHURY, M K U and SALEH, N M (1996). Determination of minimal inhibitory concentration of selection agents for oil palm (Elaeis guineensis Jacq.) transformation. Asia Pacific J. Molecular Biology and Biotechnology, 4: 219228.

PARVEEZ, G K A; CHOWDHURY, M K U and SALEH, N M (1997). Physical parameters affecting transient GUS gene expression in oil palm (Elaeis guineensis Jacq.) using the biolistic device. Industrial Crops Prod., 6: 41-50.

PARVEEZ, G K A (1998). Optimization of Parameters Involved in the Transformation of Oil Palm Using the Biolistics Method. Ph.D thesis, Universiti Putra Malaysia.

PARVEEZ, G K A; CHOWDHURY, M K U and SALEH, N M (1998). Biological parameters affecting transient GUS gene expression in oil palm (Elaeis guineensis Jacq.) embryogenic calli via microprojectile bombardment. Industrial Crops Prod,. 8: 17-27.

PARVEEZ, G K A (2000). Production of transgenic oil palm (Elaeis guineensis Jacq.) using biolistic techniques. Molecular Biology of Woody Plants (Jain, S $\mathrm{M}$ and Minocha, S C eds.). Vol. 2, Kluwer Academic Publishers. p. 327-350.

PARVEEZ, G K A; NA'IMATULAPIDAH, A M; ALIZAH, $Z$ and OMAR, A R (2007). Determination of minimal inhibitory concentration of selection agents for selecting transformed immature embryos of oil palm. Asia Pacific J. Molecular Biology and Biotechnology, 15: 133-146.

PARVEEZ, G K A and MAJID, N A (2008). Factors affecting green fluorescence protein (GFP) gene expression in oil palm after microprojectile bombardment mediated transformation. J Oil Palm Res. Vol. 20: 495-507.

PARVEEZ, G KA; RASID, O A; MASANI, M Y A and SAMBANTHAMURTHI, R (2015a). Biotechnology of oil palm: strategies towards manipulation of lipid content and composition. Plant Cell Rep., 34; 533-543.

PARVEEZ, G K A; BAHARIAH, B; AYUB, N H; MASANI, M Y A; RASID, O A; TARMIZI, A $\mathrm{H}$ and ISHAK, $\mathrm{Z}$ (2015b). Production of polyhydroxybutyrate in oil palm (Elaeis guineensis Jacq.) mediated by microprojectile bombardment of PHB biosynthesis genes into embryogenic calli. Front. Plant Sci., 6: 598. DOI:10.3389/fpls.2015.00598.

PONAPPA, T; BRZOZOWSKI, A E and FINER, J J (2000). Transient expression and stable transformation of soybean using jellyfish green fluorescent protein (GFP). Plant Cell Rep., 19: 6-12.

PUCHOOA, P (2004). Expression of green fluorescent protein gene in litchi (Litchi chinensis Sonn.) tissues. J. Appl. Hort., 6: 11-15.

RAJASEKARAN, K; CARY, J W; COTTY, P J and CLEVELAND, T E (2008). Development of a GFPexpressing Aspergillus flavus strain to study fungal invasion, colonization, and resistance in cottonseed. Mycopathologia, 165: 89-97.

SANTI, C; SVISTOONOFF, S; CONSTANS, L; AUGUY, F; DUHOUX, E; BOGUSZ, D and FRANCHE, C (2003). Choosing a reporter for gene expression studies in transgenic actinorhizal plants of the Casuarinaceae family. Plant and Soil, 254: 229237.

SHEEN, J; HWANG, S; NIWA, Y; KOBAYASHI, H and GALBRAITH, D W (1995). Green fluorescent protein as a new vital marker of cells. Plant J., 8: 777784.

SONG, I J; BAE, T W; GANESAN, M; KIM, J I; LEE, H Y and SONG, P S (2013). Transgenic HerbicideResistant Turfgrasses, Herbicides - Current Research and Case Studies in Use (Andrew Price ed.), ISBN: 978953-51-1112-2, InTech, DOI: 10.5772/56096. http:/ / www.intechopen.com/books / herbicides-currentresearch-and-case-studies-in-use / transgenicherbicide-resistant-turfgrasses.

SUNILKUMAR, $\mathrm{G}$ and RATHORE, K S (2001). Transgenic cotton: factors influencing Agrobacterium-mediated transformation and regeneration. Mol. Breed., 8: 37-52.

TARMIZI, A H; NORJIHAN, M A and ZAITON, R (2003). Multiplication of oil palm suspension 
cultures in a bench-top two litre bioreactor. J. Oil Palm Res. Vol. 16 (2): 44-49.

TEE, C S; MARZIAH, M; TAN, C S and ABDULLAH, M P (2003). Evaluation of different promoters driving the GFP reporter gene and selected targeted tissues for particle bombardment of Dendrobium sonia 17. Plant Cell Rep., 21: 452-458.

VAIN, P; WORLAND, B; KOHLI, A; SNAPE, J $\mathrm{W}$ and CHRISTOU, P (2000). Green fluorescent protein (GFP) as a vital screenable marker in rice transformation. Theor. Appl Genet, 9: 164-169.

WANG L, XUA; Y Y, LI; POWELL, R A; XU, Z H and CHONG, K (2007). Transgenic rice plants ectopically expressing AtBAK1 are semi-dwarfed and hypersensitive to 24-epibrassinolide. J. Plant Physiology, 164: 655-664.

WU, J J; LIU, Y W and SUN, M X (2011). Improved and high throughput quantitative measurements of weak GFP expression in transgenic plant materials. Plant Cell Rep., 30: 1253-1260.
XIAO Y L; REDMAN, J C; MONAGHAN, E L; ZHUANG, J; UNDERWOOD, B A; MOSKAL, W A; WANG, W; WU, H C and TOWN, C D (2010). High throughput generation of promoter reporter (GFP) transgenic lines of low expressing genes in Arabidopsis and analysis of their expression patterns. Plant Methods, 6: 18.

ZIMMER, M (2002). Green fluorescent protein (GFP): applications, structure, and related photophysical behavior. Chem Rev., 102: 759-781.

ZHAO, Q; JING, J; WANG, G; WANG J H; FENG, Y Y; XING, H W and GUAN, C F (2010). Optimization in Agrobacterium-mediated transformation of Anthurium andraeanum using GFP as a reporter. Electronic J. Biotechnology Vol. 13 No. 5. http:/ / dx.doi. org/10.2225/vol13-issue5-fulltext-2.

ZHAO, Y; GUO, L; WANG, $\mathrm{H}$ and HUANG, D (2011). Integration and expression stability of transgenes in hybriding transmission of transgenic rice plants produced by particle bombardment. Mol. Plant Breed., 2: 48-59. 